\title{
Studi Numerik Penambahan Obstacle Terhadap Kinerja Kolektor Surya Pemanas Udara dengan Plat Penyerap Jenis V-Corrugated
}

\author{
Ekadewi A. Handoyo ${ }^{1,2, a}$, Djatmiko Ichsani1 ${ }^{1, b}$, Prabowo ${ }^{1, c}$, Sutardi ${ }^{1, d}$ \\ ${ }^{1}$ Program Studi Teknik Mesin, Institut Teknologi Sepuluh Nopember, Surabaya-Indonesia \\ ${ }_{2}^{2}$ Program Studi Teknik Mesin, Universitas Kristen Petra, Surabaya-Indonesia \\ Email: aekadewi@peter.petra.ac.id, bdjatmiko@me.its.ac.id, cprabowo@me.its.ac.id, dsutardi@me.its.ac.id
}

\begin{abstract}
ABSTRAK
Kolektor surya pemanas udara dapat digunakan untuk menghasilkan udara panas dengan sumber energi yang terbarukan.Namun, perpindahan kalor dari plat penyerap ke udara sangat rendah. Beberapa peneliti melaporkan bahwa obstacle dapat meningkatkan perpindahan kalor dalam kolektor surya saluran plat datar dan peneliti lain menemukan bahwa kolektor surya dengan plat penyerap jenis v-corrugated memberikan perpindahan kalor yang lebih besar daripada saluran plat datar. Namun, belum ada penelitian yang menggabungkan keduanya. Dalam paper ini akan dibahas studi numerik dari penggabungan keduanya, yaitu penambahan obstacle terhadap kinerja kolektor surya pemanas udara dengan plat penyerap jenis $\mathrm{v}$ corrugated. Studi diawali dengan pembuatan mesh, pemberian kondisi batas, pemberian data input, dan pemilihan model turbulen. Hasil studi numerik dibandingkan dengan hasil eksperimen untuk mengetahui keabsahannya.Suatu kolektor surya pemanas udara dibangun dengan skala laboratorium untuk keperluan eksperimen ini.Eksperimen dilakukan di dalam ruangan agar kondisi lingkungan dapat dijaga konstan.Dari eksperimen didapat bahwa udara mengalami kenaikan temperatur lebih tinggi dan penurunan tekanan lebih besar saat diberi obstacle. Untuk udara dengan kecepatan $6,5 \mathrm{~m} / \mathrm{s}$ dan intensitas radiasi $430 \mathrm{~W} / \mathrm{m}^{2}$, udara mengalami kenaikan dari $24,5^{\circ} \mathrm{C}$ menjadi $37,2^{\circ} \mathrm{C}$ jika tanpa obstacle dan dari $24,3^{\circ} \mathrm{C}$ menjadi $40,5^{\circ} \mathrm{C}$ jika diberi obstacle serta peningkatan penurunan tekanan dari 94 menjadi $265 \mathrm{~Pa}$ dengan penambahan obstacle. Model turbulen yang tepat untuk studi numerik ini adalah Shear Stress Transport (SST) k- $\omega$.Dari studi numerik yang dilakukan, didapatkan bahwa aliran balik di antara obstacle dan celah sempit di antara obstacle dengan plat penyerap menyebabkan aliran lebih turbulen dan perpindahan kalor konveksi ke udara dari plat penyerap kolektor meningkat.Hasil studi numerik konsisten dengan hasil eksperimen.
\end{abstract}

Kata kunci: Kolektor surya pemanas udara, obstacle, plat penyerap v-corrugated, studi numerik.

\begin{abstract}
An air solar collector as a renewable energy source is used to provide hot air. Unfortunately, heat transferred from the absorber plate to the flowing air is very low. Some research reported that obstacles can improve heat transfer in a flat plate solar collector and the others found that $v$ corrugated absorber plate solar collector gives higher heat transfer than a flat plate solar collector. Yet, no research on combining these two was found. This paper describes the numerical study of combining these two foundings i.e. obstacles used in a v-corrugated absorber plate air solar heater. Study was initiated with mesh generating, providing boundary conditions, giving input data, and choosing turbulence model. Then, the result of numerical study is compared with experimental data to validate the result of the numerical study. An air solar heater model was built for an indoor experiment. The experiment was conducted indoor to maintain the same environment conditions. From the study and experiment, it was found that obstacles increase the air temperature rise across the collector and its pressure drop. To the air flow of $6.5 \mathrm{~m} / \mathrm{s}$ and the radiation intensity of $430 \mathrm{~W} / \mathrm{m}^{2}$, its temperature increase from $24.5^{\circ} \mathrm{C}$ to $37.2^{\circ} \mathrm{C}$ if no obstacle and from $24,3^{\circ} \mathrm{C}$ to $40,5^{\circ} \mathrm{C}$ if some obstacles were inserted. In the same conditions, the pressure drop increase from 94 to $265 \mathrm{~Pa}$ with some obstacles inserted. The suitable turbulence model for the numerical study was Shear Stress Transport (SST) $k-\omega$. From thenumericalstudiesconducted, it was found that thebackflowbetween theobstaclesand thenarrow gapbetween theobstacles and the absorberplatecausesmoreturbulentflowand enhance the convectionheat transferfrom the absorber to the flowing air. The results of numerical study is consistent with the experimental results.
\end{abstract}

Keywords: Solar air heater, obstacle, v-corrugated absorber plate, numerical study. 


\section{PENDAHULUAN}

Dengan semakin besar kepedulian terhadap lingkungan, maka kolektor surya menjadi peralatan yang sangat menarik untuk diteliti. Kolektor surya mengubah energi radiasi matahari menjadi energi termal yang kemudian dapat digunakan untuk memanaskan air atau udara. Kolektor surya pemanas udara umumnya mempunyai kinerja lebih rendah dari pemanas air. Hal ini disebabkan karena udara memiliki konduktivitas termal yang lebih kecil dibanding air dan koefisien perpindahan kalor konveksi antara permukaan plat penyerap dengan udara yang juga lebih rendah. Menurut [1], koefisien perpindahan kalor konveksi gas jauh lebih rendah dari cairan, baik untuk konveksi jenis alami ataupun jenis paksa. Di samping kekurangan yang ada, udara memiliki keunggulan seperti tidak menimbulkan masalah jika ada kebocoran, tidak korosif, dan ringan. Hal ini mendorong banyak peneliti berupaya untuk meningkatkan kinerja kolektor surya pemanas udara. Berbagai upaya yang telah dilakukan peneliti terdahulu adalah menggunakan plat penyerap yang dicat hitam atau diberi lapisan yang mempunyai absorptance tinggi dan emittance rendah [2], memasang honeycomb untuk mengurangi kalor yang hilang ke lingkungan [3], [4], [5], membuat aliran menjadi dua laluan [6], [7], [8], meningkatkan koefisien konveksi udara dengan plat penyerap dengan mempersempit saluran sehingga aliran menjadi turbulen [9], [10], menggunakan saluran dari plat bergelombang atau plat penyerap $v$ corrugated [11], [12], [13], [14], [15], [16], [17], dan membuat aliran lebih turbulen dengan menambahkan fin, baffle, atau obstacle[18], [19], [20], [21], [22], [23], [24].

Kolektor surya pemanas udara secara sederhana terdiri dari plat penyerap, plat dasar, dan kaca penutup. Plat penyerap dapat terbuat dari plat datar, plat gelombang atau plat yang ditekuk membentuk saluran segitiga atau v-corrugated. ElSebaii et al. [11] menyatakan bahwa kolektor udara dengan plat penyerap tipe $v$-corrugated mempunyai efisiensi $11-14 \%$ lebih tinggi dari kolektor dengan plat datar. Kedua kolektor yang dibandingkan merupakan kolektor dengan dua laluan.Dari studi eksperimental, Naphon [13] menemukan bahwa saluran dengan plat $v$-corrugated pada sebelah atas dan bawah menghasilkan peningkatan perpindahan kalor sebanyak 3,51 kali plat datar dan penurunan tekanan 1,96 kali lebih tinggi dari plat datar.Gao et al. [14] dan Tao et al. [15] menemukan bahwa pemanas udara tipe cross-corrugated mempunyai kinerja termal lebih baik dari tipe plat datar. Menurut Karim \& Hawlader [16], kolektor tipe $v$ corrugated lebih efisien $10-15 \%$ dari plat datar jika digunakan satu laluan dan lebih efisien 5-11\% jika digunakan dua laluan. Dua laluan memberi peningkatan efisiensi paling tinggi jika digunakan di kolektor plat datar dan paling sedikit di kolektor tipe v-corrugated. Bashria et al. [17] menemukan bahwa kolektor tipe v-corrugated memiliki efisiensi lebih tinggi dari plat datar baik dari simulasi matematis maupun dari eksperimen.

Studi eksperimen yang dilakukan Promvonge [18] dalam daerah turbulen (bilangan Reynolds antara 5000 hingga 25.000) menunjukkan bahwa baffle jenis $\mathrm{V}$ dengan sudut $60^{\circ}$ yang dipasang dalam saluran yang halus meningkatkan bilangan Nusselt dan factor gesekan. Kurtbas dan Turgut [19] meneliti pengaruh penambahan fin yang dipasang pada permukaan absorber secara tetap dan bebas. Dua fin yang digunakan mempunyai dimensi berbeda, tetapi luasan dan bentuk sama berupa empat persegi panjang. Fin (I) mempunyai dimensi $810 \times 60 \mathrm{~mm}$ dan type (II) 200x60mm. Untuk mendapatkan total luasan yang sama, ada 8 fin (I) dan 32 fin (II). Hasil yang didapatkan adalah bahwa fin (II) baik dipasang tetap maupun bebas ternyata lebih efektif daripada fin (I) dan kolektor plat datar. Fin yang dipasang tetap di kolektor lebih efektif daripada fin yang dipasang bebas. Romdhane [20] meningkatkan turbulensi dalam saluran udara dengan obstacle atau baffle. Efisiensi dan temperatur udara ditemukan mengalami kenaikan dengan penggunaan baffle, karena baffle mengarahkan aliran menuju plat penyerap. Dari penelitian dan pendekatan teoritis, Ho et al. [8] menemukan bahwa perpindahan kalor meningkat dengan digunakannya baffle aliran dua laluan dengan recycle dan fin yang dipasang di atas dan di bawah plat penyerap. Abene et al. [21] menggunakan obstacle pada kolektor surya pemanas udara plat datar untuk mengeringkan buah anggur. Obstacle meningkatkan perpindahan kalor ke udara di atas plat penyerap, menciptakan turbulensi dan mengurangi dead zone dalam kolektor. Dengan menggunakan kolektor surya dua laluan, Esen [22] meneliti tiga jenis obstacle yang dipasang di atas plat dan dibandingkan dengan plat datar biasa. Kolektor terdiri dari 3 saluran di mana udara mengalir melaluinya. Dari penelitian yang dilakukan, ditemukan bahwa obstacle jenis III dengan aliran di saluran tengah (di bawah plat penyerap) memberikan efisiensi tertinggi dan semua kolektor dengan obstacle memiliki efisiensi lebih tinggi dari kolektor plat datar.Akpinar and Koçyiğit [23] yang meneliti tiga macam obstacle menemukan bahwa obstacle jenis ke-2 memberikan efisiensi tertinggi untuk semua kondisi dan semua obstacle meningkatkan kinerja kolektor dibanding tanpa obstacle. Bekele et al. [24] menemukan secara eksperimen pengaruh dari obstacle bentuk delta yang dipasang di atas permukaan plat penyerap dari suatu saluran pemanas udara. Obstacle meningkatkan perpindahan kalor ke udara. Perpindahan kalor meningkat jika obstacle lebih tinggi dan jarak antar obstacle lebih rapat. 


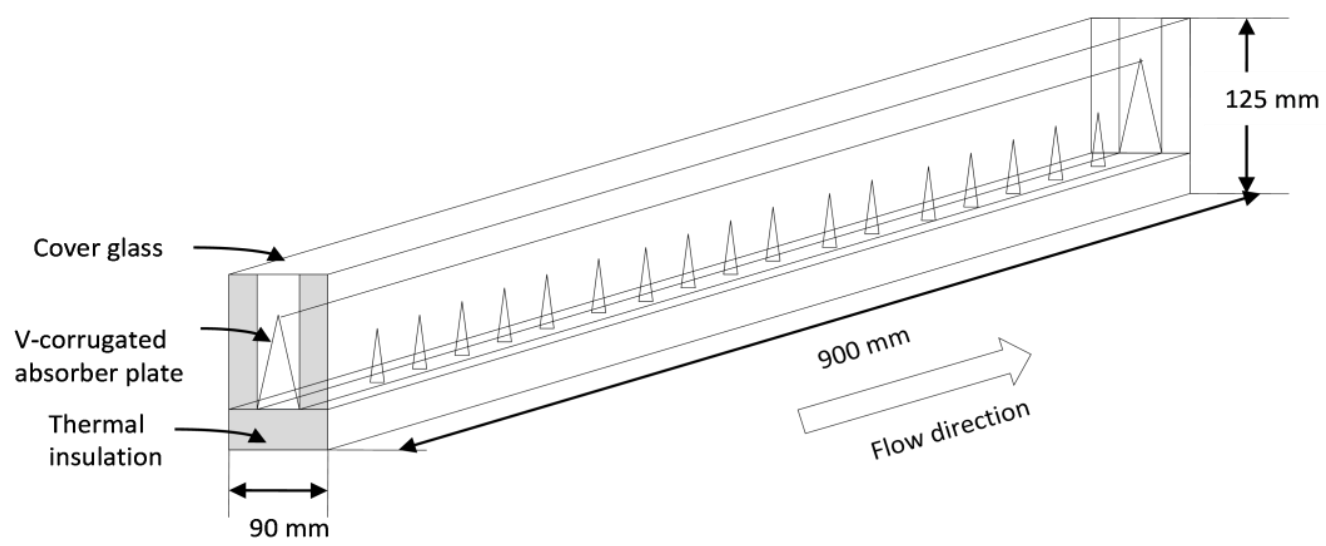

a. Gambar isometri

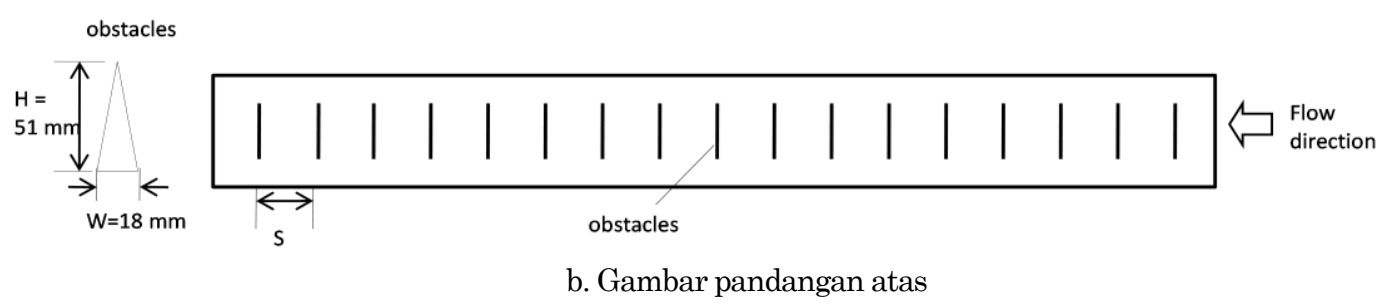

Gambar 1. Skema Kolektor Surya dengan Plat Penyerap v-corrugated dengan obstacle

Studi numerik atau Computational Flid Dynamics (CFD) merupakan metode yang sering digunakan dalam memprediksi aliran dan perpindahan kalor yang terjadi dalam suatu domain yang dipilih. Studi ini menyelesaikan persamaan kekekalan massa, kekekalan energy, persamaan Navier Stokes, dan persamaan difusi massa dengan metode finitedifference atau finite volume. Ratnam dan Vengadesan [25] membuat prediksi CFD dari aliran tiga dimensi yang tidak termampatkan dalam saluran plat datar dengan sebuah obstacle berbentuk kubus diletakkan di tengah. Mereka mencari model turbulen yang paling tepat untuk aliran yang melibatkan recirculation, separation, dan reattachment. Dua persamaan dari model turbulen yang mereka gunakan adalah standard $k$-e,low-Ryenolds numberk- $\varepsilon$, non-linear standard $k-\varepsilon$, standard $k-\omega$, dan improved $k-\omega$. Hasil CFD yang memberikan prediksi terbaik adalah model non-linear standard $k$-adan improved $k$ - $\omega$. Koefisien perpindahan kalor maksimum terjadi di dekat titik reattachment dan minimum di daerah recirculation. Srikanth et.al.[26] meneliti aliran dan perpindahan kalor pada prisma segitiga sama sisi yang terletak pada saluran horizontal datar dengan bilangan Reynolds antara 1 hingga 80 (dengan kenaikan 5), bilangan Prandtl 0,71 dan blockage ratio 0,25 secara numerik dengan software Fluent 6.3. Mereka menemukan bahwa bilangan Nusselt rata-rata dengan obstacle berbentuk segitiga sama sisi lebih besar 12,5\%-15\% dibandingkan obstacle bentuk kotak pada bilangan Reynolds antara 5-45. Szczepanik [27] melakukan studi numerik untuk mengetahui perpindahan kalor dari suatu silinder dalam aliran melintang dengan model turbulen SST k- $\omega$ dan modified $k-\omega$. Hasil yang didapat menunjukkan bahwa model modified $\mathrm{k}-\omega$ memberikan hasil prediksi yang lebih mendekati eksperimen. Eiamsa-ard dan Promovonge [28] melakukan studi numerik pada aliran paksa turbulen dalam saluran plat datar dimana terdapat beberapa cekungan kotak di plat bawah. Studi numerik dilakukan secara dua dimensi.Mereka membandingkan empat model turbulen, yaitu Standard $k-\varepsilon$, Renormalized Group (RNG) $k-\varepsilon$, Standard k- $\omega$, dan Shear Stress Transport (SST) k$\omega$.Mereka menyimpulkan bahwa model turbulen RNG dan Standard k- $\varepsilon$ memberikan hasil yang paling mendekati hasil pengukuran yang ada.

Dari pemaparan di atas, ada dua hal yang penting untuk diteliti lebih jauh.Pertama, obstacle dapat meningkatkan perpindahan kalor ke udara dalam kolektor surya plat datar. Kedua, plat penyerap v-corrugated dapat memberikan perpindahan kalor yang lebih tinggi daripada plat datar. Bagaimana jika keduanya digabung? Pada paper ini akan dibahas hasil studi numerik yang menggabungkan keduanya beserta validasi dengan percobaan yang terkait.

\section{METODE PENELITIAN}

Saluran udara yang terdapat dalam kolektor surya pemanas udara dengan plat penyerap jenis $v$ corrugated memiliki penampang segitiga sama kaki. 
Bentuk geometri yang digunakan dalam studi numerik beserta dimensinya dapat dilihat pada Gambar 1. Sudut plat penyerap adalah $20^{\circ}$ dengan dimensi panjang $900 \mathrm{~mm}$ dan sisi miring $87 \mathrm{~mm}$. Dengan demikian dimensi saluran udara yang berupa segitiga adalah lebar $30 \mathrm{~mm}$ dan tinggi 85 $\mathrm{mm}$. Obstacle yang digunakan mempunyai bentuk kongruen dengan saluran, sehingga dimensinya adalah lebar alas $18 \mathrm{~mm}$ dan tinggi $51 \mathrm{~mm}$. Obstacle diletakkan sedemikian sehingga rasio spasi terhadap tinggi, $\mathrm{S} / \mathrm{H}$, sama dengan 1 atau persentase blokir dalam saluran sebesar 36\%. Karena jarak spasi antara obstacle adalah $51 \mathrm{~mm}$, maka terdapat 17 obstacle dalam aliran.

Langkah awal dalam studi numerik adalah membuat domain dan merancang mesh dengan software Gambit 2.4.6, seperti pada Gambar 2(a) untuk aliran tanpa obstacle dan (b) untuk aliran dengan obstacle. Mesh atau grid dirancang sama untuk aliran dengan obstacle maupun tanpa obstacle. Namun, grid dirancang tidak seragam. Mesh yang lebih rapat digunakan untuk daerah dekat dinding baik plat sebelah atas (plat penyerap) maupun plat bawah seperti pada Gambar 2a. Untuk simulasi dengan obstacle, mesh juga dirancang lebih rapat di daerah dekat obstacle seperti pada Gambar 2b. Karena saluran mempunyai penampang segitiga, maka simulasi numerik harus dilakukan dalam tiga dimensi. Plat absorber dikondisikan pada temperaturkonstan sebesar $320 \mathrm{~K}$. Aliran free stream udara masuk saluran dengan kecepatan $6,5 \mathrm{~m} / \mathrm{s}$, temperatur $300 \mathrm{~K}$ dan Intensitas turbulensi 5\%. Pada plat bawah saluran dinyatakan sebagai wall yang terisolasi sempurna.
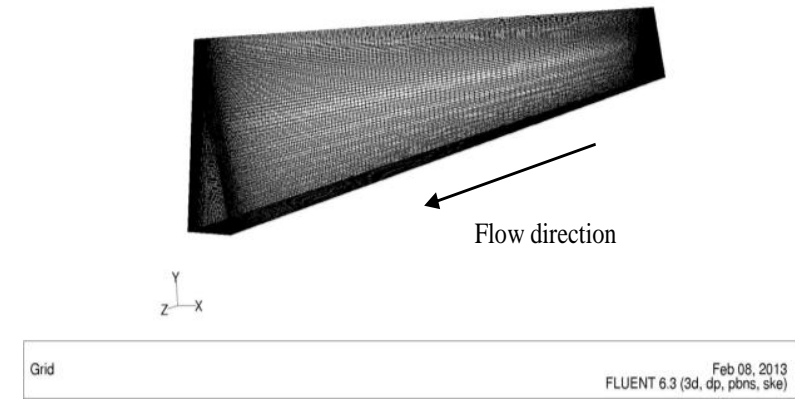

a) Aliran tanpa obstacle

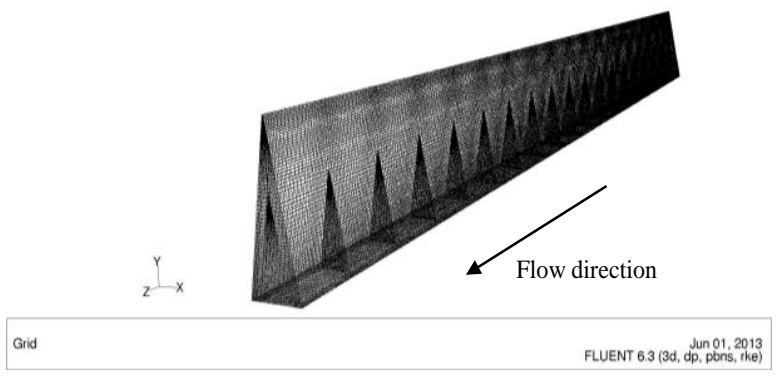

b) Aliran dengan 17 obstacle di atas plat bawah

Gambar 2. Rancangan Mesh yang Digunakan dalam Simulasi Numerik
Dengan menggunakan software CFD komersial FLUENT 6.3.26, simulasi numerik dilakukan untuk mesh yang telah dirancang. Konfigurasi mesh yang digunakan terdiri dari jumlah cell sebanyak 1.008.000, jumlah sisi permukaan sebanyak 3.080.000, dan jumlah node sebanyak 1.063.468. Dengan konfigurasi mesh yang sama, tahap selanjutnya adalah penentuan model turbulen viscous yang sesuai untuk kondisi aliran seperti pada penelitian ini. Model viscous yang digunakan adalah jenis model viscous steady state dengan dua persamaan yaitu Standard k- $\varepsilon$ (SKE), RNG k- $\varepsilon$ (RNGKE), Realizable k- $\varepsilon$ (RKE), Standard k- $\omega$ (SKW), dan Shear Stress Transport k- $\omega$ (SSTKW). Dalam melakukan simulasi numerik untuk semua model turbulen, discretization equation dipilih second order upwind discretization dan hubungan perhitungan kecepatan dan tekanan menggunakan algoritma SIMPLEC. Hasil simulasi numerik semua model viscous tersebut dibandingkan dengan hasil ekperimen. Perbandingan tersebut meliputi perbandingan kenaikan temperatur udara keluar dan masuk serta penurunan tekanan udara dalam saluran. Eksperimen dilakukan dalam ruangan agar kondisi lingkungan selalu terjaga. Upaya ini dilakukan untuk menghindari perbedaan hasil karena kondisi luar yang tidak sama. Eksperimen menggunakan peralatan dengan skema dan foto seperti pada Gambar 3. Eksperimen dilakukan dengan kolektor surya pemanas udara dalam skala model di laboratorium di PS Teknik Mesin, Universitas Kristen Petra, Surabaya.

Radiasi matahari dimodelkan dengan empat buah lampu halogen yang masing-masing menggunakan daya 500 Watt. Selama eksperimen, intensitas radiasi yang diterima di permukaan kaca penutup diukur dengan pyranometer (Kipp \& Zonen, type SP Lite2). Setiap lampu dilengkapi dengan dimmer terpisah, sehingga radiasi yang diterima di seluruh plat absorber dapat diatur agar seragam dengan nilai tertentu, yaitu $430 \mathrm{~W} / \mathrm{m}^{2}$. Kolektor yang dipakai dilengkapi dengan enam termokopel tipe $\mathrm{T}$ dengan ketelitian $0,1^{\circ} \mathrm{C}$ untuk mengukur temperatur udara masuk dan ke luar, temperatur plat penyerap di empat lokasi berbeda. Penurunan tekanan antara udara masuk dan keluar kolektor diukur dengan Magnehelic differential pressure gage dengan ketelitian $2 \mathrm{~Pa}$. Suatu blower sentrifugal $\left(1000 \mathrm{~m}^{3} / \mathrm{h}, 580 \mathrm{~Pa}, 0,2 \mathrm{~kW}, 380\right.$ Volt input) digunakan untuk mengalirkan udara melalui saluran secara induced. Laju aliran udara diukur di keluaran dengan anemometer digital yang mempunyai ketelitian $0,1 \mathrm{~m} / \mathrm{s}$. Laju udara yang mengalir diatur dengan mengubah frekuensi putara motor dengan variable-frequency drive (VFD). Pada eksperimen, laju aliran udara ke luar diatur konstan sebesar 5,0 m/s. Angka ini setara dengan kecepatan aliran $6,5 \mathrm{~m} / \mathrm{s}$ di dalam saluran. 


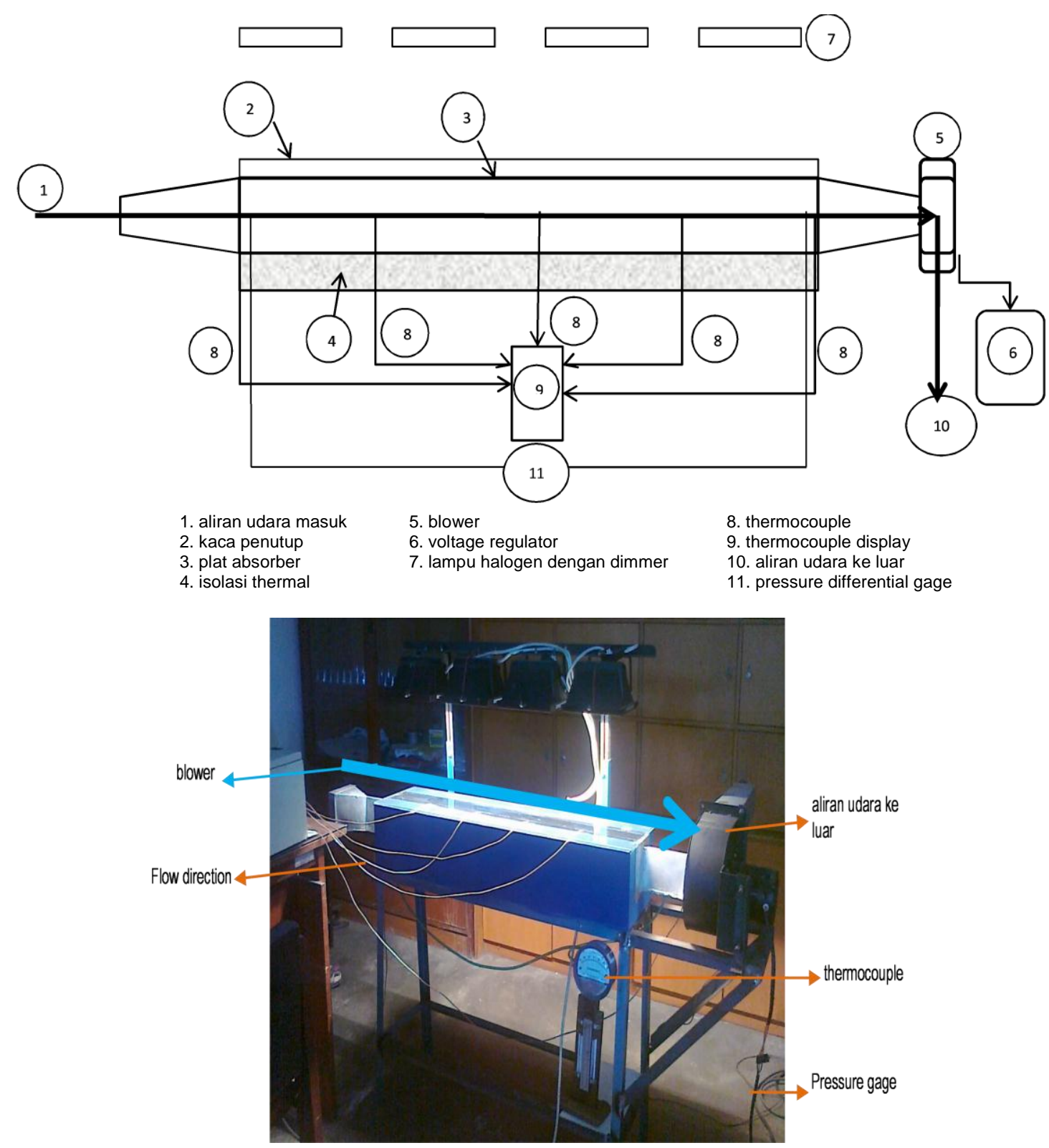

Gambar 3. Skema dan Foto Peralatan yang Digunakan dalam Eksperimen

\section{HASIL DAN PEMBAHASAN}

Dengan konfigurasi mesh seperti pada Gambar 2, didapat perbandingan hasil simulasi numerik dengan eksperimen untuk kenaikan temperatur dan beda tekanan seperti pada Gambar 4. Laju aliran udara di keluaran ditetapkan pada $5,0 \mathrm{~m} / \mathrm{s}$ (atau 6,5 $\mathrm{m} / \mathrm{s}$ dalam saluran di kolektor) dan intensitas radiasi $430 \mathrm{~W} / \mathrm{m}^{2}$. Dari Gambar 4 terlihat bahwa model turbulen SSTKW memberikan prediksi yang paling mendekati hasil eksperimen. Hal ini sesuai dengan panduan yang diberikan Fluent [29], bahwa model turbulen SSTKW sesuai untuk aliran dengan banyak separasi dan vortex.

Gambar 5 menunjukkan vektor kecepatan aliran udara di centerline dalam saluran dengan plat penyerap bentuk $v$-corrugated yang dihasilkan dari simulasi numerik. Gambar 5a untuk aliran tanpa obstacle dan Gambar 5b untuk aliran dengan obstacle. Agar sesuai dengan eksperimen, maka kecepatan udara di inlet ditentukan $6,5 \mathrm{~m} / \mathrm{s}$ untuk studi numerik ini. Untuk aliran tanpa obstacle, kecepatan udara semakin tinggi di tengah saluran dan mengecil di daerah dekat plat penyerap maupun plat bawah.Sedang untuk aliran dengan obstacle, kecepatan udara tampak lebih tinggi di daerah di atas obstacle. Hal ini disebabkan luas penampang saluran mengecil dengan adanya obstacle. Jika dibandingkan pada Gambar 5a dan $5 b$, terlihat bahwa kecepatan udara dekat plat penyerap sebelah atas lebih rendah jika tidak diberi obstacle. Ketika sebagian udara mengenai obstacle, udara menempel pada obstacle dan turun ke bawah dengan kecepatan rendah seperti pada Gambar 6b. 


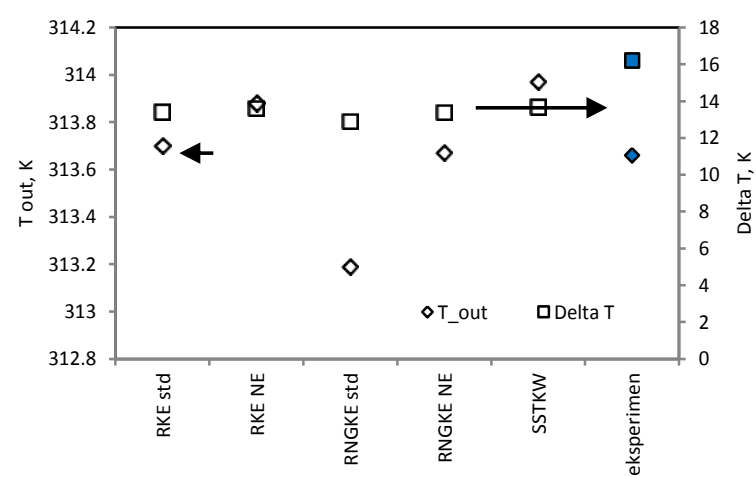

a. Temperatur ke luar dan kenaikan temperatur

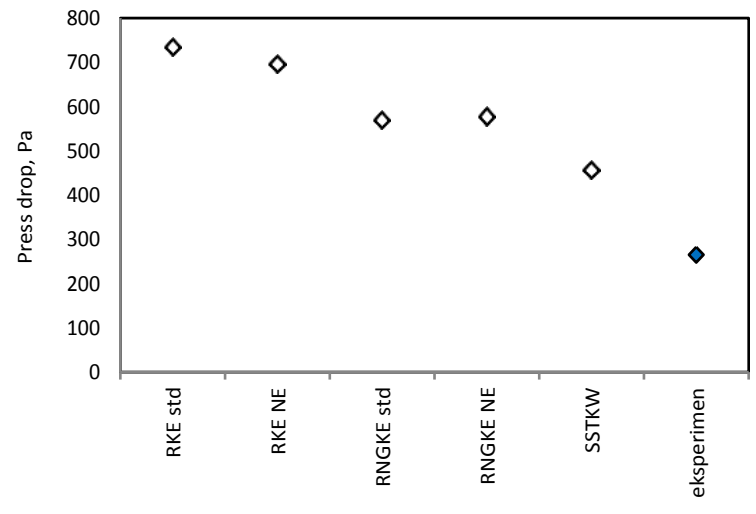

b. Penurunan tekanan aliran udara

Gambar 4. Perbandingan antara Hasil Simulasi Numerik dengan Eksperimen

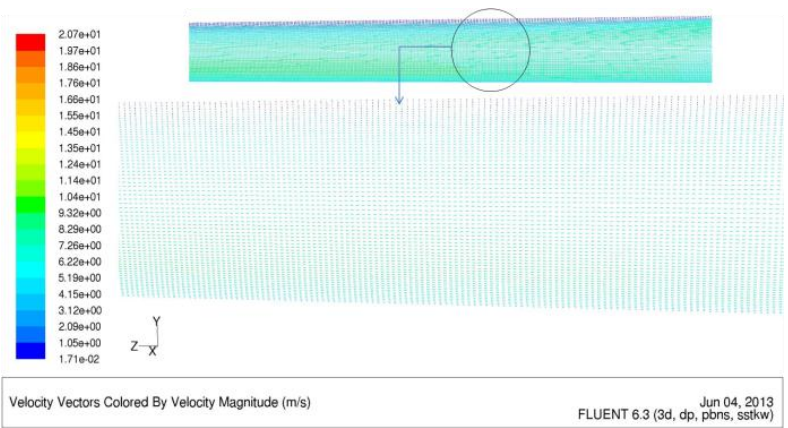

a. Vektor kecepatan udara di centerline saat tanpa obstacle

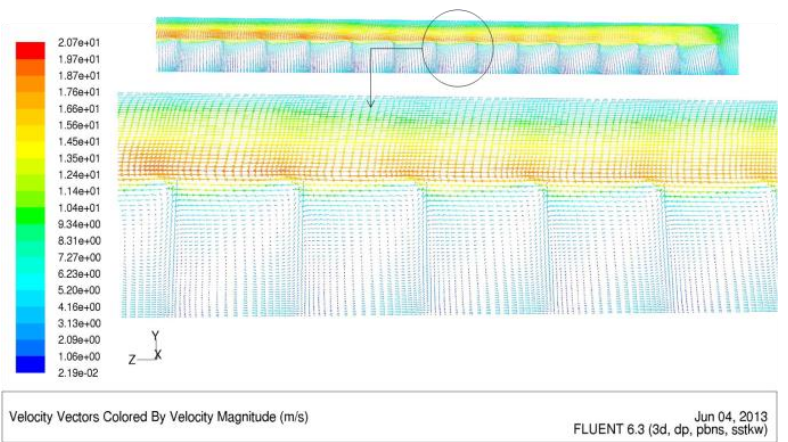

b. Vektor kecepatan udara di centerline dengan obstacle

Gambar 5. Vektor Kecepatan Udara di Centerline dengan Kecepatan Udara di Masukan $=6,5 \mathrm{~m} / \mathrm{s}$

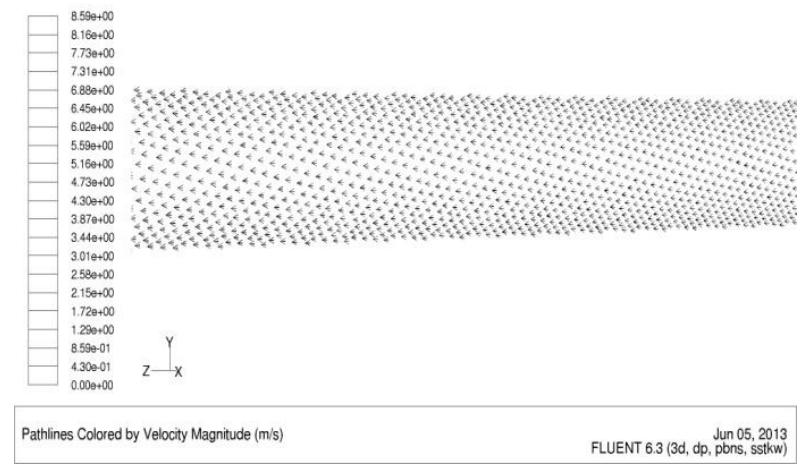

a. Pathline aliran udara di centerline saat tanpa obstacle

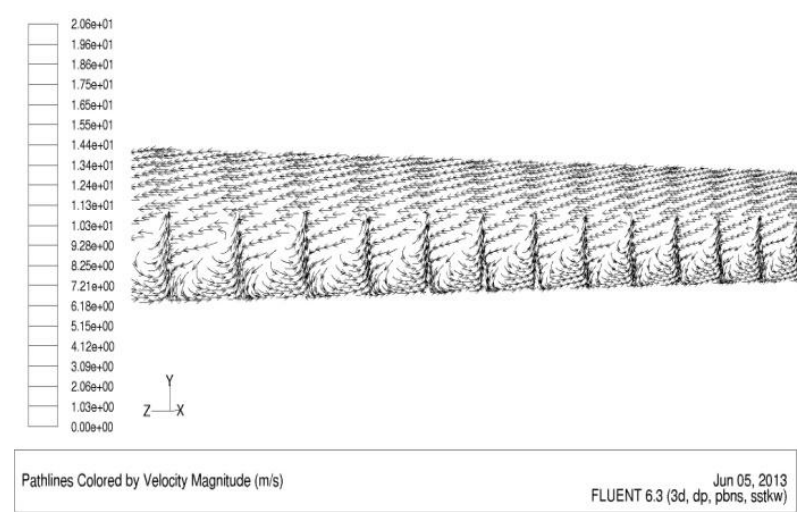

b. Pathline aliran udara di centerline dengan obstacle

Gambar 6. Pathline Aliran Udara di Centerline dengan Kecepatan Udara di Masukan $=6,5 \mathrm{~m} / \mathrm{s}$

Kemudian udara mengenai obstacle yang di depannya dan menimbulkan aliran balik. Obstacle meningkatkan turbulensi dan mengarahkan aliran menuju plat penyerap yang panas. Hal ini membuat perpindahan kalor konveksi antara udara dengan plat penyerap meningkat, sehingga kenaikan temperatur udara saat mengalir dalam kolektor juga meningkat. Gambar 6a terlihat bahwa tidak terjadi aliran balik dalam aliran tanpa obstacle.

Peningkatan perpindahan kalor dapat diketahui dari kenaikan temperatur udara. Dari eksperimen, udara mengalami kenaikan temperatur dari $24,5^{\circ} \mathrm{C}$ menjadi $37,2^{\circ} \mathrm{C}$ jika tanpa obstacle dan dari $24,3^{\circ} \mathrm{C}$ menjadi $40,5^{\circ} \mathrm{C}$ jika diberi obstacle. Hasil ini bersesuaian dengan simulasi numerik. Temperatur udara ketika melintasi kolektor dengan obstacle lebih tinggi daripada jika tanpa obstacle seperti pada Gambar 7a dan 7b. Temperatur udara dalam saluran tidak memiliki distribusi yang seragam, udara dekat plat penyerap yang di sebelah atas mempunyai temperatur lebih tinggi dari yang dekat plat bawah.Dengan obstacle, terjadinya aliran balik atau vortex membuat temperature udara di antara obstacle meningkat seperti pada Gambar 7b. Hal ini membuat udara ke luar kolektor dengan temperatur lebih tinggi dibandingkan aliran tanpa obstacle. 


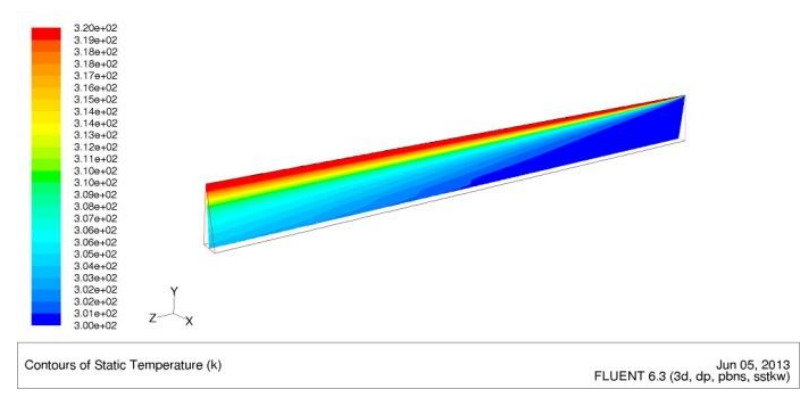

a. Distribusi temperatur udara di centerline saat tanpa obstacle

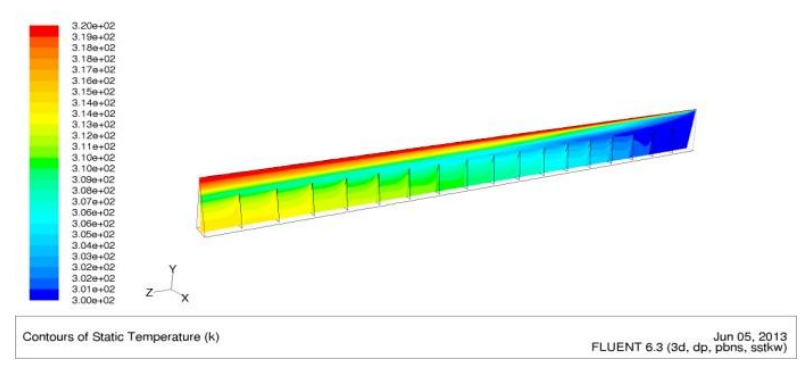

b. Distribusi temperatur udara di centerline saat tanpa obstacle

Gambar 7. Distribusi Temperatur Udara di Centerline saat Temperature Plat Penyerap $320 \mathrm{~K}$

\section{KESIMPULAN}

Dari eksperimen pada suatu kolektor pemanas udara dengan plat penyerap jenis v-corrugated, udara mengalami kenaikan temperatur lebih tinggi dan penurunan tekanan lebih besar saat diberi obstacle. Untuk udara dengan kecepatan $6,5 \mathrm{~m} / \mathrm{s}$ dan intensitas radiasi $430 \mathrm{~W} / \mathrm{m}^{2}$, udara mengalami kenaikan dari $24,5^{\circ} \mathrm{C}$ menjadi $37,2^{\circ} \mathrm{C}$ jika tanpa obstacle dan dari $24,3^{\circ} \mathrm{C}$ menjadi $40,5^{\circ} \mathrm{C}$ jika diberi obstacle serta peningkatan penurunan tekanan dari 94 menjadi 265 Pa dengan penambahan obstacle.

Model turbulen yang tepat untuk studi numerik ini adalah SSTKW. Dari studi numerik yang dilakukan, didapatkan bahwa aliran balik di antara obstacle dan celah sempit di antara obstacle dengan plat penyerap menyebabkan aliran lebih turbulen dan perpindahan kalor konveksi ke udara dari plat penyerap kolektor meningkat.

Hasil studi numerik konsisten dengan hasil eksperimen.

\section{PENGHARGAAN}

Penulis sangat bersyukur untuk hibah penelitian yang diterima dari Kopertis Wilayah VII Jawa Timur, Kementerian Pendidikan dan Kebudayaan dengan kontrak no. 0004/SP2H/PP/K7/KL/II/2012.

\section{DAFTAR PUSTAKA}

[1] I. P. Frank and D. P. DeWitt, Fundamentals of Heat and Mass Transfer, $5^{\text {th }}$ ed, John Wiley \& Sons., 2002.
[2] A. A. El-Sebaii and H. Al-Snani, "Effect of selective coating on thermal performance of flat plate solar air heaters," Energy, Vol. 35, pp. 1820-1828, 2010.

[3] A. H. Abdullah, H. Z. Abou-Ziyan and A. A. Ghoneim, "Thermal performance of flat plate solar collector using various arrangements of compound honeycomb," Energy Conversion and Management, Vol. 44, pp. 3093-3112, 2003.

[4] A. A. Ghoneim, "Performance optimization of solar collector equipped with different arrangements of square-celled honeycomb," International Journal of Thermal Sciences, Vol. 44, pp. 95-105, 2005.

[5] H. Suehrcke, D. Daldehog, J. A. Harris and R. W. Lowe, "Heat transfer across corrugated sheets and honeycomb transparent insulation," Solar Energy, Vol. 76, pp. 351-358, 2004.

[6] S. Chamoli, R. Chauhan, N. S. Thakur and J. S. Saini, "A review of the performance of double pass solar air heater," Renewable and Sustainable Energy Reviews, Vol. 16, pp. 481-492, 2012.

[7] P. Naphon, "On the performance and entropy generation of the double-pass solar air heater with longitudinal fins," Renewable Energy, Vol. 30, pp. 1345-1357, 2005.

[8] C.-D. Ho, H.-M. Yeh and T.-C. Chen, "Collector efficiency of upward-type double-pass solar air heaters with fins attached," International Communications in Heat and Mass Transfer, Vol. 38, pp. 49-56, 2011.

[9] W. Sun, J. Ji and W. He, "Influence of channel depth on the performance of solar air heaters," Energy, Vol. 35, pp. 4201-4207, 2010.

[10] Y. Islamoglu and C. Parmaksizoglu, "The effect of channel height on the enhanced heat transfer characteristics in a corrugated heat exchanger channel," Applied Thermal Engineering,23, pp. 979-987, 2003.

[11] A. A. El-Sebaii, S. Aboul-Enein, M. R. I. Ramadan, S. M. Shalaby and B. M. Moharram, "Investigation of Thermal Performance of Double-pass-flat and V-corrugated Plate Solar Air Heaters," Energy, Vol. 36, pp. 1076-1086, 2011a.

[12] P. Naphon, "Effect of wavy plate geometry configurations on the temperature and flow distributions," International Communications in Heat and Mass Transfer, Vol. 36, pp. 942946, 2009.

[13] P. Naphon, "Heat transfer characteristics and pressure drop in channel with $\mathrm{V}$ corrugated upper and lower plates," Energy conversion and management,48, pp. 1516 - 1524, 2007.

[14] W. f. Gao, W. x. Lin, L. Tao Liu and C. f. Xia, "Analytical and experimental studies on the thermal performance of cross-corrugated and 
flat-plate solar air heaters," Applied Energy,84, pp. $425-441,2007$.

[15] L. Tao, X. L. Wen, F. G. Wen and X. L. Chan, "A Parametric study on the termal performance of a solar air collector with a V-groove absorber," International Journal of Green Energy, 4, pp. 601-622, 2007.

[16] M. A. Karim and M. N. A. Hawlader, "Performance Investigation of Flat Plate, $V$ corrugated and Finned Air Collector," Energy, 31, pp. 452-470, 2006.

[17] A. A. Bashria, N. M. Adam, S. M. Sapuan, M. Daud, H. Omar, H. M. Megat and F. Abas, "Prediction Of The Thermal Performance Of Solar Air Heaters By Internet-Based Mathematical Simulation," Proceedings of the Institution of Mechanical Engineers, pp. 579-587, 2004.

[18] P. Promvonge, "Heat transfer and pressure drop in a channel with multiple $60^{\circ} \mathrm{V}$-baffles," Int. Com. in Heat and Mass Transfer, Vol. 37, pp. 835-840, 2010.

[19] I. Kurtbas and E. Turgut, "Experimental Investigation of Solar Air Heater with Free and Fixed Fins: Efficiency and Exergy Loss," Int. J. of Science \& Technology, Vol. 1, No 1, pp. 75-82, 2006.

[20] B. S. Romdhane, "The air solar collectors: Comparative study, introduction of baffles to favor the heat transfer," Solar Energy, Vol. 81, pp. 139-149, 2007.

[21] A. Abene, V. Dubois, M. Le Ray and A. Oagued, "Study of a solar air flat plate collector: use of obstacle and application for the drying of grape," J. of Food Engineering, Vol. 65, pp. 15-22, 2004.
[22] H. Esen, "Experimental energy and exergy analysis of a double-flow solar air heater having different obstacle on absorber plates," Building and Environment, Vol. 43, pp. 1046-1054, 2008.

[23] E. K. Akpinar and F. Koçyiğit, "Experimental investigation of thermal performance of solar air heater having different obstacle on absorber plates," Int. Com. in Heat and Mass Transfer, Vol. 37, pp. 416-421, 2010.

[24] A. Bekele, M. Mishra and S. Dutta, "Effects of Delta-Shaped Obstacle on the Thermal Performance of Solar Air Heater," Hindawi Publishing Corporation: Advances in Mechanical Engineering, Vol. 2011, pp. 10 pages, 2011.

[25] G. S. Ratnam and S. Vengadesan, "Performance of two equation turbulence meodels for prediction of flow and heat transfer over a wall mounted cube," International Journal of Heat and Mass Transfer, No. 51, pp. 2834-2846, 2008.

[26] S. Srikanth, A. K. Dhiman and S. Bijjam, "Confined flow and heat transfer across a triangular cylinder in a channel," International Journal of Thermal Sciences, No. 49, pp. 21912200, 2010.

[27] K. Szczepanik, A. Ooi, L. Aye and G. Rosengarten, "A numerical study of heat transfer from a cylinder in cross flow," $15^{\text {th }}$ Australasian Fluid Mechanics Conference, 2004.

[28] S. Eiamsa-ard and P. Promvonge, "Numerical study on heat transfer of turbulent channel flow over periodic grooves," International Communications in Heat and Mass Transfer, No. 35, pp. 844-852, 2008.

[29] FLUENT, FLUENT User's Guide, 2003. 